\section{AEC \\ RESEARCH and}

DEVELOPMENT

REPORT

\title{
PRTR FUEL ELEMENT RUPTURE TEST FACILITY CAPABILITIES AND PROJECT HISTORY
}

MARCH 1, 1965

BNWL - 40
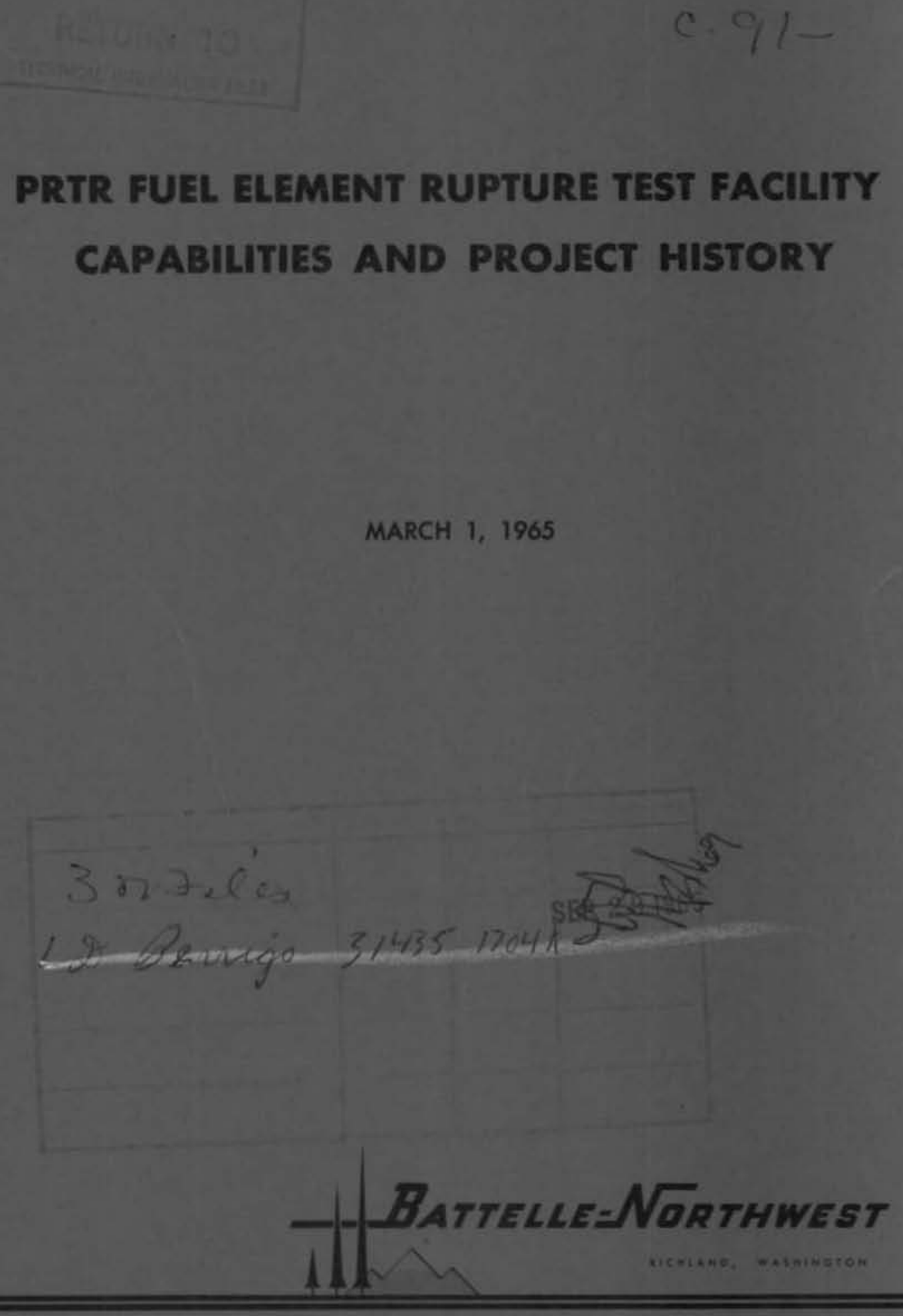

PACIFIC NDRTHEST LABORATORY ODERATES OY BATTELLE MEMORIAL INSTITUTE 


\section{LEGAL NOTICE}

This report was prepared as an account of Government sponsored work. Neither the Unifed States, nor the Cormmission, nor any person acting on behalf of the Commission:

A. Makes any warranty or representation, expressed or implied, with respect to the accuracy, com. pleteness, or usefulnest of the information containad in this report, or that the use of any information, apparatus, method, or process disclosed in this report may nof infringe privately owned rights; or

B. Assumes any liobilities with respect to the use of, of for damages cesulting from the use of any information, apparatus, method, or process disclosed in this report.

As used in the obove, "person acting on behalf of the Commission" includes ony employee or contractor of the Commission, or employee of such contractor, to the extent that such employee or con. fractor of the Commission, or emplayee of such contractor prepares, disseminates, ar provides access to, any informotion pursuant to his employment or contract with the Commission, or his employment with such contractor 


\section{PRTR FUEL ELEMENT RUPTURE TEST FACILITY}

\section{CAPABILITIES AND PROJECT HISTORY}

By

P. C. Walkup

Maintenance and Equipment Engineering Section

Test Reactor and Engineering Services

March 1, 1965

PACIFIC NORTHWEST LABORATORY

RICHLAND, WASHINGTON

FIRST MARETRETCO

DISTRIEUICOA MALE

APR 14 ' 65

Work performed under Contract No. AT(45-1)-1830 between the Atomic Energy Commission and Battelle Memorial Institute.

Printed by/for the U. S. Atomic Energy Commission 


\section{PRTR FUEL ELEMENT RUPTURE TEST FACILITY}

CAPABILITIES AND PROJECT HISTORY

$$
\text { P. C. Walkup }
$$

$\underline{\text { Page }}$

I. INIRODUCTION . . . . . . . . . . . . . . . . . . . . . . 1

II. FACILITY DESCRIPTION . . . . . . . . . . . . . . . . . 1

III. LOOP CAPABILITIES . . . . . . . . . . . . . . . 10

A. Operating Parameters . . . . . . . . . . . . 12

B. Single Pass Capability . . . . . . . . . . . . 14

C. Water Activity Measurement . . . . . . . . . . 16

D. Test Fuel Elements . . . . . . . . . . . . . . 17

E. Possible Additional Capabilities . . . . . . . . . . . . I7

IV. ENGINEERING INFORMATION . . . . . . . . . . . . . 18

A. Coolant System . . . . . . . . . . . . . . 18

B. Makeup System . . . . . . . . . . . . . . 20

C. Cleanup System .................. . . 2l

D. Decontamination System . . . . . . . . . . . . . . 22

E. Test Section . . . . . . . . . . . . . . . . 22

V. PROJECT HISTORY . . . . . . . . . . . . . . . . . . 24

A. Design .. . . . . . . . . . . . . . . . 24

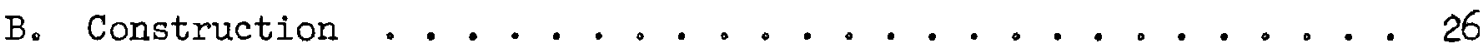


I. INTRODUCTION

A. The Plutonium Recycle Test Reactor Fuel Element Rupture Test Facility (Rupture Loop) was put into reactor service in November, 1963. Since that date it has been used in support of Plutonium Recycle Program fuels development. The primary purpose of this document is to disseminate pertinent information relative to capabilities and limitations to potential users of the facility. The history of the facility, as a construction project, is also recorded.

\section{FACILITY DESCRIPTION}

The fuel element rupture test facility is a part of the Plutonium Recycle Test Reactor (PRTR) complex. This test facility is a research and development tool for work in nuclear fuel technology. The objectives of the program for which the facility was designed were:

1. Development of fuel design features that will mitigate rapid destruction of corrodible fuels after jacket failure.

2. Develop fuel rupture detection instruments of high reliability.

3. Determine interaction of rupturing fuel elements in pressurized zircaloy tubes.

4. Test decontamination techniques.

5. Test advanced plutonium recycle program fuel elements.

As originally conceived, the facility was to be used in support of the New Production Reactor metallic fuel development program. However, at the time the loop was ready for activation it was concluded that sufficient fuel failure information had been obtained. The facility has been used, to date, for irradiating "pre defected" ceramic fuel elements. The following detailed description is based on the capability of the system with respect to both corrodible and ceramic fuel testing. Descriptions of the 
Plutonium Recycle Test Reactor are given elsewhere(1) and are not included herein.

The facility consists of the following components: (2)

1. A system for removing the heat generated in the in-reactor test section by circulating light water through the section and the appropriate piping, heat exchangers, valves, and tanks.

2. An in-reactor section, installed in one of the 85 PRTR fuel channels, including the devices for holding test fuel elements in place and inducing fuel jacket penetrations.

3. A water filtration plant capable of supplying treated Columbia River water to the loop as makeup and to the PRTR secondary coolant system.

4. A cleanup and effluent disposal system for removing contaminants from the coolant and for safely disposing of the effluent coolant when the facility is operated on "single pass."

5. A makeup system for supplying filtered, deoxygenated, and demineralized water to the facility as leakage compensation makeup and when the facility is operated on "single pass."

6. Auxiliary systems including equipment for decontaminating the coolant loop and for feeding chemicals into the makeup stream.

7. Instrumentation and controls for the above systems.

Figure 1 shows an elementary flow diagram of the coolant system and its auxiliaries. Figure 2 shows the locations of the various components. The coolant water is pumped by two positive displacement pumps from a low

(1) Plutonium Recycle Test Reactor Final Safeguards Analysis, edited by N. G. Wittenbrock, HW-61236, October 1, 1959.

(2) Walkup, P.C., et. al., Design Criteria for the PRTR Fuel Element Rupture Testing Facility, Project CAH 867, HW-63863, April 1, 1960. 
pressure storage tank and passes through a regenerative heat exchanger. It then passes through two electric immersion heaters and flows to the inlet of the test section tube. After passing through the reactor, the coolant flows through the shell side of the regenerative heat exchanger and transfers most of its sensible heat to the inlet water. The coolant is then cooled further to a temperature of about $120 \mathrm{~F}$ as it passes through a cooling heat exchanger. Cooling water is supplied to this unit from the water filtration plant via the PRTR secondary coolant system. The coolant then flows through an ion exchange cleanup system and to the storage tank, or, on single pass operation, through the cleanup system to an outside holdup tank.

The part of the system at low temperature and pressure is located outside the containment envelope. Containment is effected by the closure, on high PRIR effluent liquid activity, of an automatic valve in the line downstream of the cooler and a check valve in the pump discharge line. Should the containment valve close, coolant flow through the test section is maintained by the opening of relief valves on the downstream side of the test section. The effluent from these relief valves is discharged inside the containment vessel.

Flow through the test section is controlled by a bypass valve (RL-I). Pressure is controlled by regulating a throttling valve (RL-3). Temperature is controlled by regulating both the output of the electric immersion heaters and the coolant flow rate through the inlet side of the regenerative heat exchanger.

The system is designed for tube outlet temperatures as great as $600 \mathrm{~F}$, at a tube outlet pressure of 2,000 psig, with a flow rate of $200 \mathrm{gpm}$ (referenced to $70 \mathrm{~F}$ ), and a maximum fuel power of $1800 \mathrm{kw}$. Parts of the system outside 


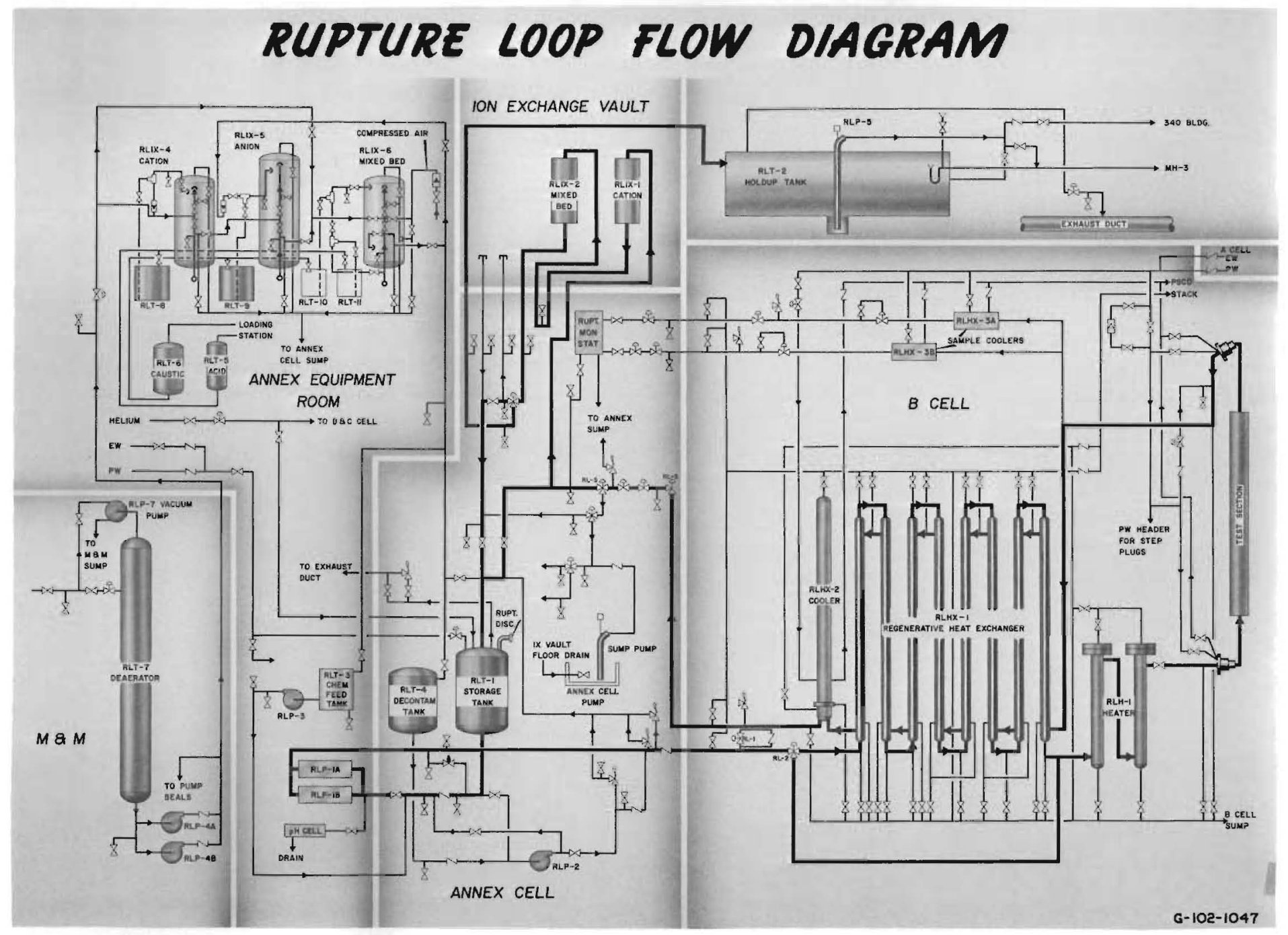

FIGURE I

FUEL ELEMENI RUPTURE TEST FACILITY - FLOW DIAGRAM 


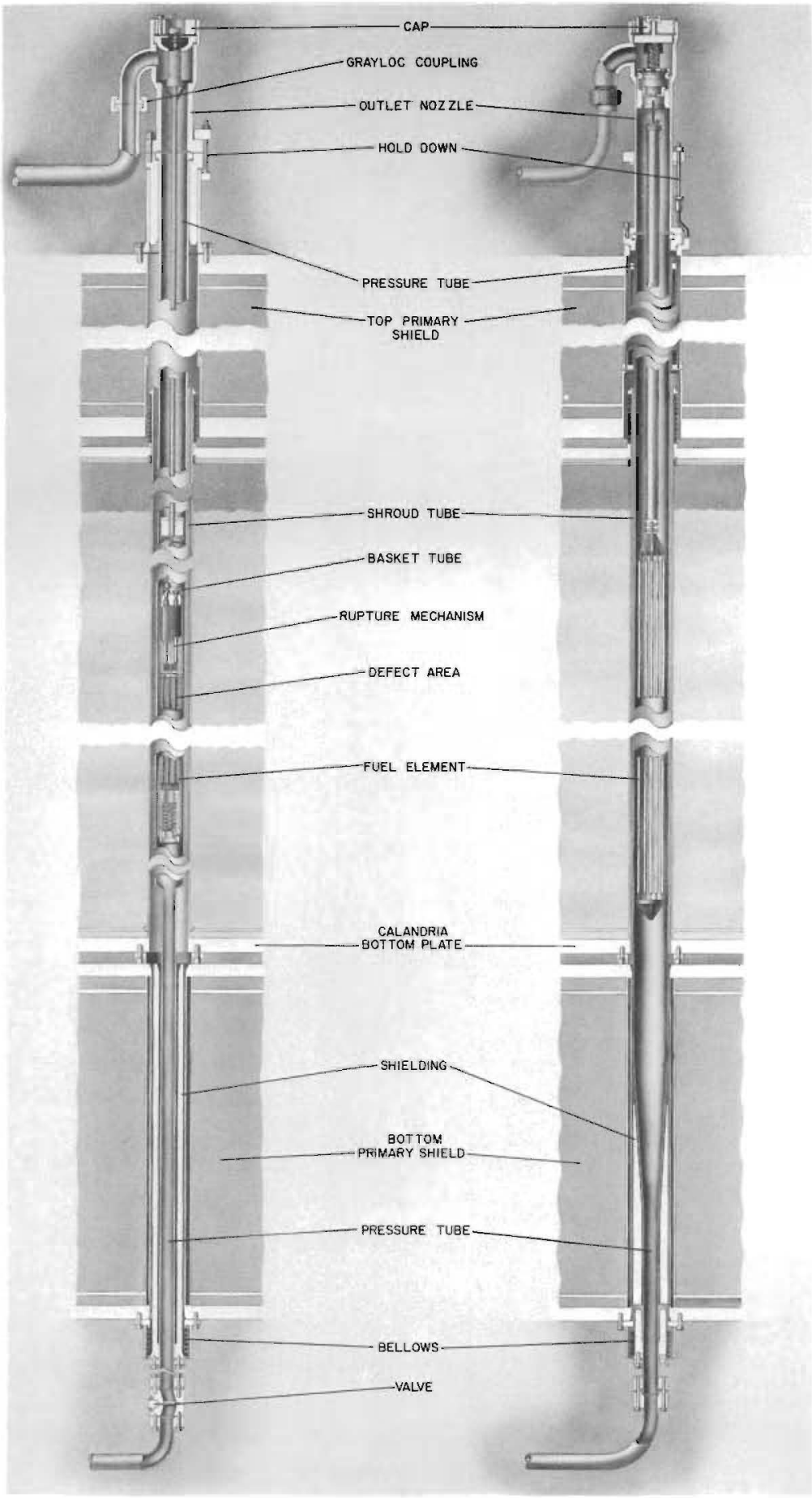

$6-102-1046$

FIGURE 2

FUEL ELEMENT RUPTURE TEST FACILITY - TEST SECTIONS 
the reactor and in contact with the cooling water are fabricated of stainless steel; the in-reactor pressure tube is constructed of zirconium. The pressure tube is flanged to the piping system and can be easily exchanged.

Single-pass capability was designed into the system to provide for direct measurement of fuel fission product release to the coolant without rapid background increase and to permit any desired degree of dilution of fission products. Fission product release kinetics can then be investigated for systems from straight recirculation to straight single-pass and for any intermediate point between the two. Intermediate points would simulate the fission product release from the fuel of the single channel of a multichannel reactor.

Referring again to Figure 1, manipulation of a three-way (RL -5) valve permits the coolant to return to the low pressure storage tank or to an ion exchange system. The ion exchange system consists of a mixed bed ion exchanger and a cation exchanger which are designed to remove ionized fission products and other fuel debris from the coolant for a period of two years at a projected test schedule rate (100 grams corroded per test for 12 tests per year). Coolant flows from the mixed bed ion exchanger to a retention tank. From the retention tank, the treated water is disposed of either directly to a sewer or is transferred to a liquid load-out facility and transported by truck to disposal grounds.

Operation of the system on single-pass would deplete the level of storage water in the low pressure tank; a full flow makeup system is provided for replenishment. The makeup system consists of a water filtration plant, a vacuum deoxygenerator and three ion exchangers in series. The water filtration plant supplies treated Columbia River water to the reactor secondary coolant system in parallel with the loop deoxygenator and ion exchanger. 
The deoxygenerator is a packed vertical tank operated at a pressure such that the water boils. The deoxygenated water is pumped from this unit to a cation, an anion, and a mixed bed ion exchanger. Water flows directly through the units to the loop storage tank at rates up to $210 \mathrm{gpm}$. A small automatically controlled pump and a tank are provided for injection of lithium hydroxide between the mixed bed ion exchanger and the storage tank for makeup pH control.

Parts of the system become radioactive after fuel tests are conducted; facilities are provided for chemically decontaminating the system so that it may be returned to service without undue restriction on personnel access. These facilities consist of tanks, transfer pumps, etc., for handling and circulating decontaminating chemicals through the loop pipes and equipment. Steel shielding is provided around the piping and equipment inside the containment envelope in areas which must be accessible during a fuel test ( $3^{\prime \prime}$ on piping and $6^{\prime \prime}$ around heat exchanger vessels).

The described arrangement of equipment was chosen because:

1. Single-pass capability requires minimum duplication of equipment.

2. Conversion to and from single -.pass can be accomplished with little temperature disturbance.

3. Rapid cool-down after fuel rupture can be effected, if desired.

4. System operating temperatures, pressures, and flows can be easily controlled over wide ranges with a minimum of complex equipment.

5. Much of the equipment and piping can be located outside the containment envelope.

6. Good contamination control is possible because cooling the entire flow stream permits the entire flow stream to be treated by ion exchange resins. These resins cannot be used at high temperature. 
7. One hundred percent makeup capability reduces the effects of a piping failure downstream of the test section. Such a piping failure if not adequately provided for, can lead to fuel melting in a closed recirculating system.

Components of the system described are largely commercially designed and fabricated. Quality standards, however, were substantially higher than normal commercial requirements.

Several safety features have been designed into the primary cooling system of the facility; these are described in detail along with an overall hazards review elsewhere. (3) For protection against electrical power failure, flywheels are provided on the positive displacement coolant supply pump drives. These flywheels are large enough to provide an adequate level of cooling water circulation for a period of at least one minute after power failure. The flywheels thus permit safe shutdown of the reactor and flow decay to the point where one pump at low speed, which is energized by the normal or an emergency power supply, will provide adequate flow, or emergency water can be injected, with fuel powers up to $1800 \mathrm{kw}$. Two independent backup power supplies are provided for each of the circulating pump drives. Protection against a piping failure is provided by an intertie between the Rupture Loop and the PRTR secondary coolant water: water is automatically injected into the Rupture Loop coolant system in the event of low-pressure, as would be caused by a piping failure.

Additional protection of the reactor against coolant stoppage and fuel melting is provided in the form of instrumentation. Reactor shutdown will

(3) H. E. Hanthorn, Plutonium Recycle Test Reactor Final Safeguards Analysis Supplement 5, Fuel Element Rupture Testing Facility Analysis, HW-61236 Sup. 5, May, 1963. 
occur automatically on low coolant flow, abnormal test section inlet pressure, low level in the storage tank, high differential pressure across the test section or high test section outlet temperature. Reliability and protection against spurious trips are provided by the use of coincident circuitry and redundant sensors such that when any two out of three primary sensing elements indicate abnormal conditions, the reactor is automatically shut down. In addition to the automatic reactor shutdown mechanism, the containment valves previously mentioned are connected to the PRTR containment system such that high activity in the outgoing water streams causes all containment valves to automatically close.

The in-reactor test section which was designed and procured for the New Production Reactor fuel testing is as shown as the high pressure assembly on Figure 3. This arrangement was specifically designed to accommodate prototype fuel and is not suitable for PRTR elements. It has not been used in-reactor but has undergone thorough out-of-reactor design testing at design conditions (2000 psig, $600 \mathrm{~F}$ ). Referring to Figure 3, the assembly consists of a thick-walled zircaloy tube, a basket tube which surrounds the test fuel element, and the hardware for suspending the fuel and holding it in place. The test section assembly is arranged to fit into a normal PRTR. channel with minimum alteration of the conventional process channel parts. The test fuel element is suspended by means of a hanger rod from the top nozzle. This hanger rod also supports a manually controlled mechanism for penetrating the fuel jacket while the fuel element is exposed to the desired environmental conditions. This mechanism is either a hydraulicallyoperated chisel which will sever a small appendage welded to the fuel jacket, or a hydraulically-operated saw which will saw a slit through the test fuel element jacket. The first method has been successfully used several times for similar test work at the experimental test reactors at the National 
Reactor Testing Station. The second method has been tested out of reactor and successfully used in a single in-reactor test. The thin-walled basket tube which surrounds the test fuel element is intended to isolate the pressure tube from the fuel element and the possible damaging effects of hydrogen which may be evolved when test fuel elements react with coolant. In addition, the basket tube will tend to protect the pressure tube from mechanical damage by swelling ruptured fuel elements.

The planned use of the facility involved the testing of metallic fuel elements which might exhibit pyrophoric behavior on exposure to air. The PRTR fueling vehicle air cools fuel elements being removed from the reactor. Special procedures were therefore developed to enable the use of this vehicle. for discharging the loop. These procedures involved removal of the pressure tube with the fuel element and providing a system to circulate water through the tube and fuel element in transit.

$(4)(5)$

The PRTR in-reactor assembly, as shown on Figure 3, consists of a normal PRTR zircaloy tube with standard PRTR connecting jumpers, outlet nozzle, and connections.

In addition to the in-reactor assemblies, a six foot section of $21 / 2$ inch piping downstream of the test section was recently replaced with a coupon holding section; this enables exposure of metallic coupons to the coolant at full operating conditions for film deposition and corrosion studies.

\section{LOOP CAPABILITIES}

Loop operating characteristics corresponding to the more restrictive of

(4) P. C. Walkup, Fuel Element Rupture Test Facility Discharge Method, HW-771I7, April 1, 1963.

(5) D. L. Ballard, Development, Testing and Preliminary Operating Instructions Fuel Element Rupture Testing Facility - Discharge Equipment, HW-75643, December 12, 1962 . 


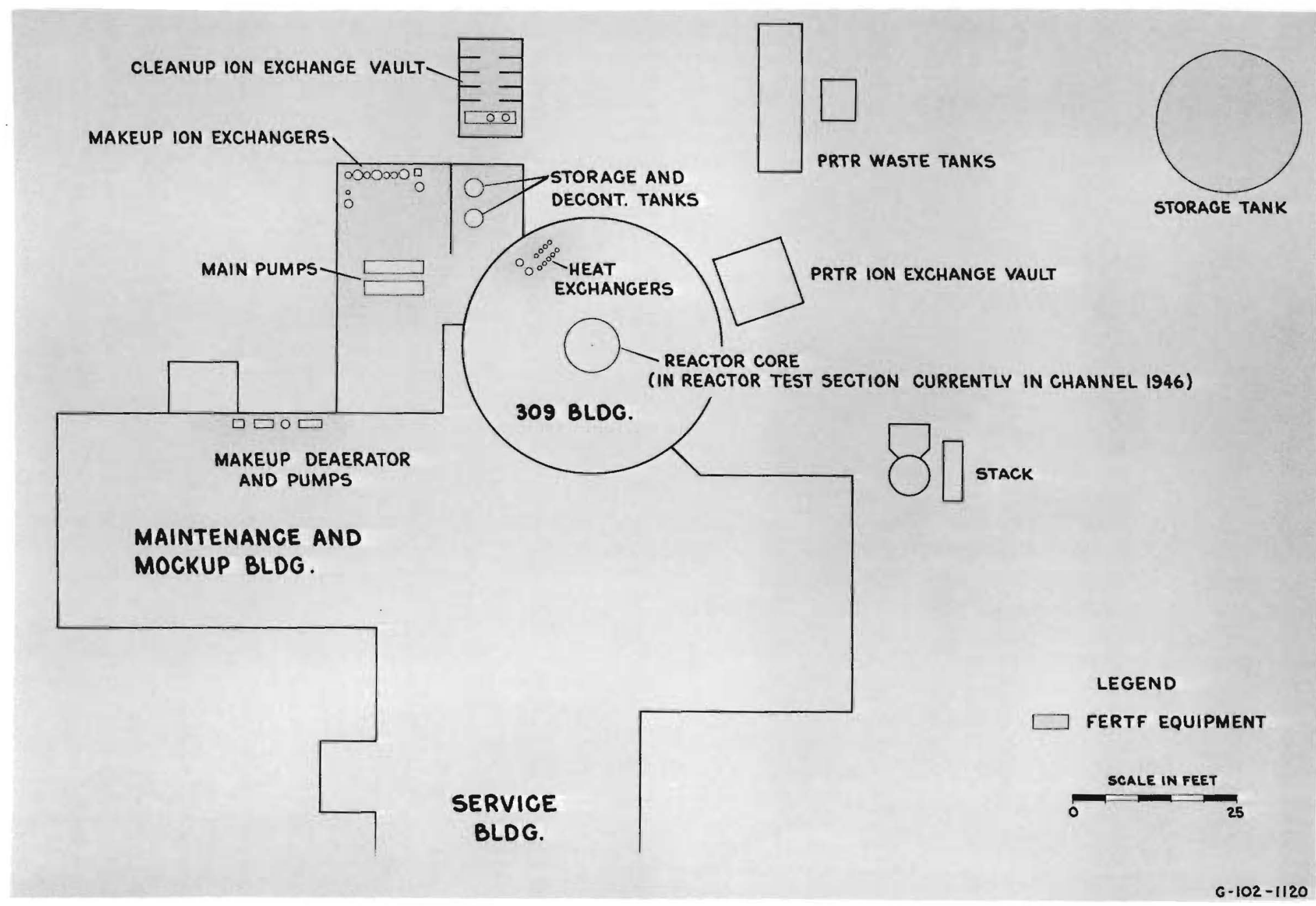

\section{FIGURE 3}

FUEL ELEMENT RUPTURE TEST FACILITY - PLOT PLAN 
design or performance limitations based on actual tests are given in the following paragraphs.

\section{A. Operating Parameters}

1. Main loop coolant flow - Each of the two main circulating pumps is rated at $105 \mathrm{gpm}$ at full speed for a total maximum loop coolant flow of $210 \mathrm{gpm}$. Hazards considerations dictate that both pumps be in operation during reactor operation; one may be operated at high speed and one at low speed for a total flow of $126 \mathrm{gpm}$ at the pump temperature $(120 \mathrm{~F})$. The minimum flow could be further decreased by increasing the size of the flow control valve or increasing the size of the valve trim.

2. Loop Temperature - As previously stated, the low temperature and low pressure parts of the coolant system are outside the PRTR containment vessel; all components of the high temperature part of the system are designed for operation at $600 \mathrm{~F}$ (piping valves, heat exchangers, heaters). All components of the low temperature part of the system are designed for $120 \mathrm{~F}$. A standard PRTR tube assembly (including jumper material, outlet nozzle and pressure tube) has been used to date as the in-reactor test section. The limiting design factor for these components, temperature wise, is the pressure tube with a maximum allowable outlet temperature of $550 \mathrm{~F}$ at $1000 \mathrm{psi}$.

The originally planned test section was designed for operation at $600 \mathrm{~F}$ at inlet and outlet pressures of 2100 and 2000 psig, respectively. This section is available and could be used for experiments as required.

(6) P. C. Walkup, Design Tests - Fuel Element Rupture Test Facility, HW-71516, undated. 
The coolant system operates as an "open cycle" with the water coolant being heated to the desired temperature upstream of the test section inlet by transfer of heat from the test section effluent and by the use of electrically energized heaters; the maximum test section outlet temperature attainable, with a fixed maximum heater energy output and fixed regenerative heat exchanger size, is dependent on the coolant flow rate and the energy output from the test section. The relationship between these variables is shown on Figure 4, which shows the required test section power as a function of coolant flow rate and maximum attainable test section outlet temperature.

3. Loop pressure - Components of the coolant system external to the reactor are designed to be compatible with minimum test section bulk outlet operating conditions of $600 \mathrm{~F}$ and 2000 psig.

With the use of a standard PRTR tube assembly loop pressure is Iimited to 1150 psig at the test section inlet. With the use of the high pressure test section assembly full design pressures of 2100 psig inlet and 2000 psig outlet are feasible.

4. Neutron Flux - The present approximate thermal, epithermal, and fast neutron fluxes at the center of the fringe fuel channel in which the test section is installed are $3.5 \times 10^{13}, 4 \times 10^{13}$, and $2.4 \times 10^{12} \mathrm{nv}$, respectively. These flux levels will increase by as much as $70 \%$ when current plans for increasing the PRTR power level and modifying the core materialize. Flux levels could be increased further by relocating the test section in a more central fuel channel or by charging more highly enriched fuel elements in adjacent channels. 
B. Single Pass Capability

The system is designed for single pass operation to afford a means of measurement of fission product release rate. During such operation the test section effluent passes through a series of ion exchangers and flows to a holdup tank; makeup is provided by a pump set, vacuum deaerator, and a series of ion exchangers. The length of time for which the system can be on single pass is dependent on the holdup tank volume ( 74,500 gallons), the integrated capacity of the makeup ion exchange system ( 115,000 gallons) and the rate of flow. 


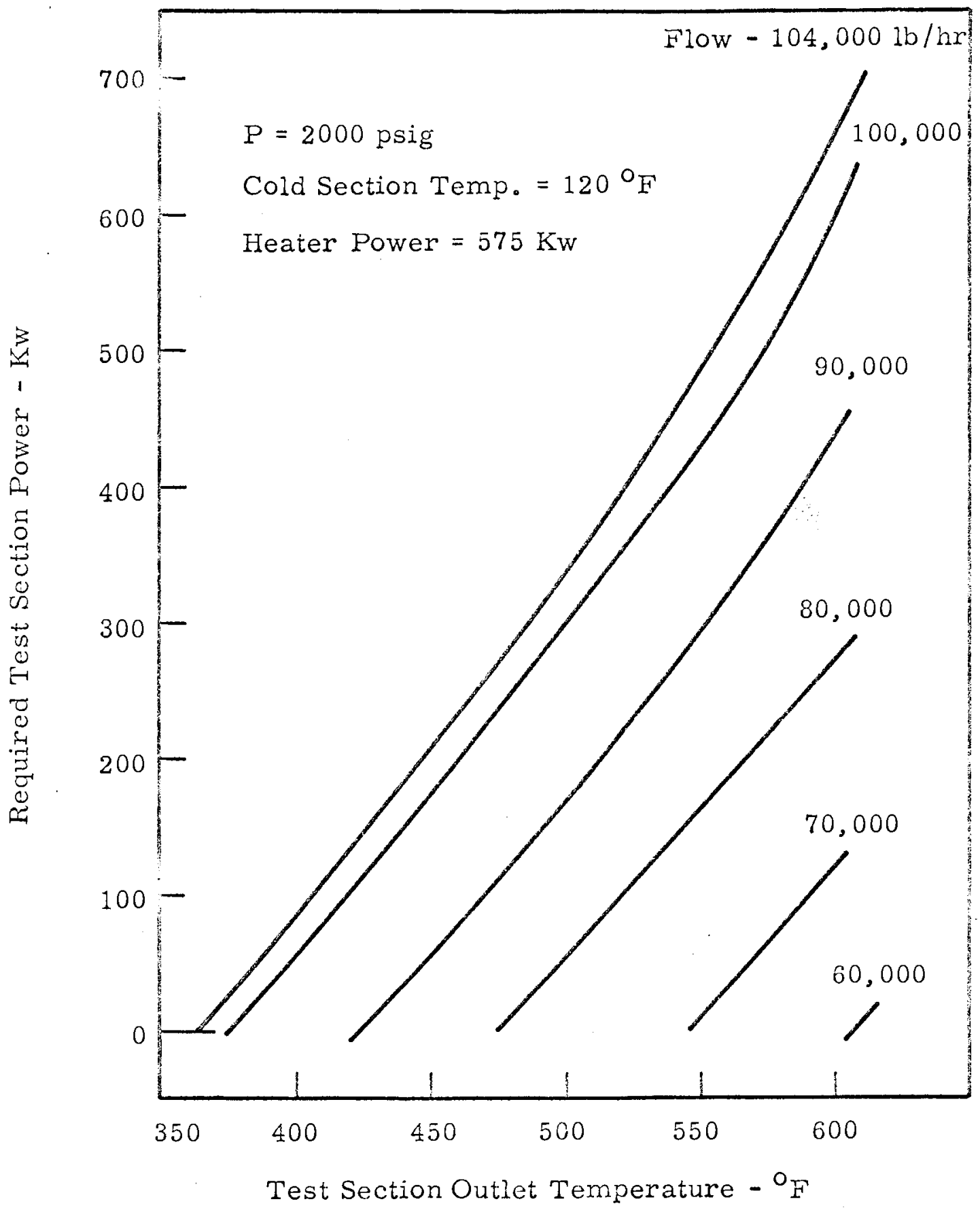

\section{FIGURE 3}

FERTF Outlet Temperature Capability 
The rate of flow to the holdup tank is dependent on the number and speed of the main pumps in operation. Time limits are:

\begin{tabular}{|c|c|c|c|}
\hline Pump Combination & $\begin{array}{r}\text { Flow } \\
\text { Rate } \\
\text { (GPM) } \\
\end{array}$ & $\begin{array}{l}\text { Hours on Single } \\
\text { Pass as Limited } \\
\text { by Holdup Tank }\end{array}$ & $\begin{array}{l}\text { Hours on Single } \\
\text { Pass as Limited } \\
\text { by Makeup System } \\
\end{array}$ \\
\hline Two pumps at High Speed & 210 & 5.9 & $9 \cdot 1$ \\
\hline $\begin{array}{l}\text { One pump at High Speed } \\
\text { One pump at High speed }\end{array}$ & 105 & 11.8 & 18.2 \\
\hline plus one pump at low speed & 126 & 9.8 & 15.2 \\
\hline One purmp at low speed & 21 & 59.2 & 91.2 \\
\hline
\end{tabular}

The holdup tank is equipped with a pump rated at $100 \mathrm{gpm}$ to empty the holdup tank via a contaminated liquid waste trucking system or the Columbia River. Certain types of experiments might permit the operation of this pump on a continuous basis during single pass operation of the facility and substantially extend the single pass capability。

\section{Water Activity Measurement}

Two sample systems connected to the main coolant system downstream of the test section, each provide continuous depressurized and cooled loop samples to a series of activity detectors. The sample flow rate is remotely controlled and may be adjusted from 0.1 to $1 \mathrm{gpm}$. These flows correspond to holdup times of 0.5 to 5.2 minutes between the outlet of the test section and the monitoring point.

Activity measurement equipment for each sample system includes:

(a) Delayed neutron $-\mathrm{BF}_{3}$ chamber. Recorded readout $10^{2}$ to $10^{6}$ counts/min. $\log$ and $5 \times 10^{2}$ to $10^{6}$ counts $/ \mathrm{min}$. linear with decade switching.

(b) Gross gamma - GM chamber. One sampling system has 0-300 counts/sec. current measuring and recording system. The other system has loglinear count rate meter and recorder with $5 \times 10^{2}$ to $10^{6}$ counts/min. Log mode and $10^{2}$ to $10^{6}$ counts $/$ min. linear mode. 
(c) Gamma scintilation - NaI crystal. Dual channel spectrometer with bucking capability for reactor power level change compensation, $\log$ and linear recording $\left(5 \times 10^{2}\right.$ to $10^{6}$ counts/min.) One 512 channel analyzer is provided which is equipped with XY plotter, typewriter printout, and tape punch unit.

D. Test Fuel Elements

Fuel elements to be irradiated in the FERTF are limited by the following dimensions:

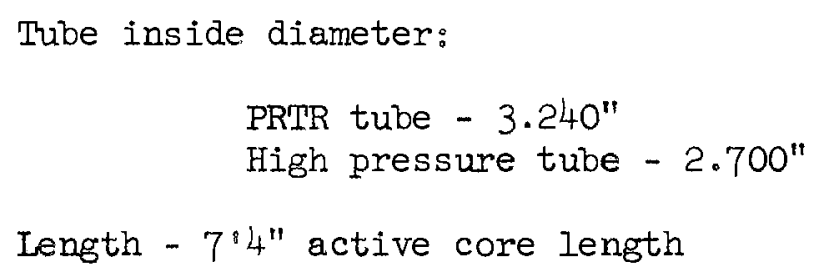

E. Possible Future Additional Capabilities

The capability of the Fuel Element Rupture Testing Facility is periodically compared to the anticipated requirements of future experimental programs. Several modifications have been recently proposed to enhance the ability. of this facility to accomplish anticipated programs. These proposed improvements are subject to further review before implementation but are listed here to indicate the additional capabilities which can be achieved at nominal cost:

1) Provide additional piping and instrumentation to enable the loop to cool two PRTR fuel channels in series or in parallel. This arrangement would be helpful in conducting non-defect irradiation tests of fuel element designs for which the probability of fuel jacket failure may be greater than for standard fuel.

2) Install a filter and/or a hydroclone downstream of the in-reactor section to retain fuel debris after failure. These devices would enable the study of the characteristics of fuel debris and would also 
increase the efficiency of operation of the loop by reducing the frequency of decontamination.

3) Modify the existing piping to enable decontamination of the loop and maintenance on the main pumps while the PRTR is in operation.

4) Install pulsation dampening devices to reduce the pressure pulsations resulting from the positive displacement pumps. These pumps produce pulsations of about \pm 150 psi at a frequency of $30 \mathrm{cps}$ at their discharge. They are reduced to about $\pm 30 \mathrm{psi}$ at the test section by the natural dampening effect of the piping and vessels between the pumps and the in-reactor section. Commercially produced devices are proposed which would reduce these pulsations by about $75 \%$ for fuel tests which might be sensitive to pressure pulse produced vibration and flow pulsation.

\section{ENGINEERING INFORMATION}

This section contains detailed information regarding equipment and performance characteristics of the Fuel Element Rupture Test Facility.

\section{A. Coolant System}

1. Loop Storage Tank (RLT-I)

Material - 304 Stainless Steel

Diameter - $4 \mathrm{ft.} 6$ in.

Volume - 880 gallons (including two 85 gallon ellipsoidal heads)

Design pressure - 20 psig

Design temperature - $300 \mathrm{~F}$

Operates with 5 psig helium blanket

2. Coolant pumps (RIP $I A$ and $1 B$ )

Material - 304 stainless steel with 329 stainless steel plungers

Type - Reciprocating vertical inverted with five 2 in. diameter plungers and 5 in. stroke 
Rated discharge pressure - 2200 psig

Rated inlet pressure - 10 psig

Rated flow - $105 \mathrm{gpm}$ at motor speed of $1800 \mathrm{rpm}$

21 gpm at motor speed of $360 \mathrm{rpm}$

Rated temperature - $120 \mathrm{~F}$

Drive - two speed (1850/360 rpm) $440 \mathrm{~V}$ synchronous motor with $5500 \mathrm{lb} \cdot \mathrm{ft}^{2}$ flywheel and $5.393 / 1$ gear reducer

3. Regenerative heat exchanger (RLHX-1)

Material - 316 stainless steel

Type - Fixed tube sheet, single pass, with $3 / 8$ in., BWG 20 tubes in eight $20 \mathrm{ft}$. long $\times 8 \mathrm{l} / 2 \mathrm{in.}$ diameter shells in series Area - $1840 \mathrm{sq}$. ft.

Volume - 305 gallons (200 gallons on shell side)

Rated service heat transfer coefficient $-718 \mathrm{BTU} / \mathrm{hr} \cdot \mathrm{ft}^{2}-\mathrm{F}$

Design temperature - $600 \mathrm{~F}$

Design pressure - 2400 psig

4. Electric immersion heater (RLH-l)

Type - Direct electrical immersion, $440 \mathrm{~V}$

Material - 316 stainless steel shell, 347 stainless steel sheathing on heating elements

Rating - 42 watts/sq. in.

Total output - $600 \mathrm{kw}$

Volume (2 shells ) - 63 gallons

Shell design temperature - $600 \mathrm{~F}$

Shell design pressure - 2400 psig

5. Cooling heat exchanger (RLHX-2)

Type - Two pass with U-tubes - 14 in. diameter x $20 \mathrm{ft}$. long shell with $3 / 4$ in. BWG 16 tubes 
Material -- 304 stainless steel tubes and tube chest, carbon steel shell

Area - 439 sq. ft.

Volume - 40 gallons (tube side only)

Rated service heat transfer coefficient - $252 \mathrm{BTU} / \mathrm{hr}-\mathrm{ft}^{2}-\mathrm{F}$

6. Piping

Material - $316 \mathrm{H}$ stainless steel

Size $-21 / 2 \mathrm{in.} \mathrm{sch.} 80 \mathrm{in}$ high pressure part of system 2 in. sch. 40 in low pressure part of system

7. Valves

Material - 316 stainless steel

Types - diaphragm operated flow, temperature, and pressure control globe valves and hand operated globe and gate valves for shutoffs, vents, and drains.

B. Makeup System

1. Vacuum deaerator (RLT-7)

Rated Capability - 210 gpm of water with outlet oxygen content of $0.2 \mathrm{ppm}$

Vacuum pump - Single stage $535 \mathrm{rpm}$ rotary piston with $131 \mathrm{cu}$. ft./min. displacement and $5 \mathrm{hp}-440 \mathrm{~V}$ drive

Material - Carbon steel with rubber lining

Size - 2 ft. 6 in. diameter x 26 ft. tall with 400 gallon treated water storage

Packing - $12 \mathrm{ft}$. deep bed of 1 l/2 in. Rashig rings

2. Makeup pumps (RLP 4A, 4B)

Material - Cast iron casing and bronze impellers

Type - Single stage, vertically split, self venting centrifugal

Rated discharge pressure - 170 psig 
Rated flow - $210 \mathrm{gpm}$

Drive - $440 \mathrm{~V}, 3600 \mathrm{rpm}, 40 \mathrm{hp}$

3. Ion exchange system ( $\operatorname{RLIX}-4,5,6)$

Rated capability - 115,000 gallons of water with 4.2 grams/gal.

as $\mathrm{CaCO}_{3}$ inlet and outlet conductivity of less than one micromho Cation column (RLIX-4)

Resin volume - $40 \mathrm{cu}$. ft.

Capacity - $13 \mathrm{kgr}$ as $\mathrm{CaCO}_{3} / \mathrm{cu}$. ft.

Resin type - strongly acidic (Illco C-2ll)

Anion column (RLIX-5)

Resin volume - $40 \mathrm{cu}$. ft.

Capacity - $13 \mathrm{kgr}$ as $\mathrm{CaCO}_{3} / \mathrm{cu}$. ft.

Resin type - strong base guartenary anine (IIIco A-464)

Mixed bed column (RLIX-6)

Resin volume - $19 \mathrm{cu}$. ft.

Capacity - $7 \mathrm{kgr}$ as $\mathrm{CaCO}_{3} / \mathrm{cu}$. ft.

Resir type - 3/2 mixture of anion/cation resin

Each ion exchanger is "Koroseal" lined and equipped for regeneration using $\mathrm{H}_{2} \mathrm{SO}_{4}$ and/or $\mathrm{NaOH}$.

C. Cleanup System

1. Ion Exchangers (RLIX 1, 2)

Type - Non-regenerable with quick disconnect external connections and graded gravel bed supports

Material - Carbon steel shells with stainless steel distributors

and external piping

Resin - Cation ( $R L I X-1) \quad 20 \mathrm{cu}$. ft. of nuclear grade sulfonic base in Lithium form (Rohm and Hoas XE 163 or equivalent)

- Mixed bed (RLIX-2) 20 cu. ft. of nuclear grade mixed bed 
resin in Lithium Hydroxide form (Rohm \& Hoas XE 154 or equivalent)

Location - Underground vault with storage space for 12 exhausted exchangers

Estimated Replacement Rate - once/two years

2. Holdup Tank (RLT-2)

Type - Steel tank, internally supported, on a concrete base Material - Carbon steel

Drain pump - Deep well, carbon steel, $100 \mathrm{gpm}, 100 \mathrm{TDH}, 5 \mathrm{hp}$ drive

Tank size - 74,500 gallons, 40 ft. diameter

Location - underground - buried

D. Decontamination System

1. Decontamination pump (RLP-2)

Type - Close coupled, single stage, centrifugal with $3500 \mathrm{rpm}$, $440 \mathrm{~V}, 5 \mathrm{hp}$ drive

Material - 316 stainless steel

Rated flow - 50 gpm

Rated pressure - 50 psig at discharge - Pump casing designed for 150 psig static

2. Decontamination tank (RLT-4)

Material - 304 stainless steel

Diameter - 4 ft. 6 in.

Volume - 700 gallons

Heater - $18 \mathrm{kw}$ with thermostat control

Mixer - 1/3 hp portable

E. Test Section

1. PRTR Assembly 
a. Pressure tube - Zircaloy - 2

Inside diameter $3 \cdot 260 / 3.240$ in.

Outside diameter 3.600 in. maximum; 0.150 in. minimum wall

b. Nozzle - 304 stainless steel

Nozzle cap - Stainless steel with spiral wound gasket seal

c. Jumper piping

$13 / 4$ in. O.D. $\times 0.083$ in. wall, 316 stainless steel

d. Connections

Outlet jumper - Parker flare

Inlet jumper - split ring retained flange

e. Seals

Pressure tube/nozzle - spiral wound gasket

Pressure tube/shield (top) - copper gasket

Pressure tube/shield(bottom - bellows with zirconium seal ring)

2. High Pressure Assembly

a. Pressure tube - Zircaloy 2

Inside diameter $-2.877 / 2.862$ in.

outside diameter - 3.600 in. maximum; 0.342 in. minimum wall

b. Nozzle - 316 stainless steel

Nozzle cap - stainless steel with spiral wound gasket

c. Jumper piping

$11 / 2$ in. sch. 80316 stainless steel pipe

a. Connections

Outlet jumper - Gralok* coupling

Inlet jumper - split ring retained flange

*Metal to metal gasket seal - proprietary design by Gray

Tool Co., Houston, Texas. 


\section{e. Seals - Same as PRTR assembly}

V. PROJECT HISTORY

This section briefly outlines the history of the Fuel Element Rupture Test Facility along with supplemental information regarding the schedule of the project.

\section{A. Design}

The basic functions of the facility, as originally conceived, were (a) as an evaluation tool in the development of means for mitigating rapid deterioration of metallic fuel elements whose jackets fail during service in high temperature water coolant, (b) as a facility for testing fuel jacket failure detection techniques and equipment, (c) to test coolant system decontamination techniques and materials, (d) to performance test advanced PRTR oxide type fuel elements, and (e) as a tool to evaluate what interaction, if any, exists between rupturing fuel elements and zirconium pressure tubes. The initial concept of a system to perform these functions was documented in 1959.(7)(8) Work on the design criteria began in February, 1960, and was approved in June of 1960. (9) Design and construction funds were authorized in June of 1960 and detail design was started. Detail design was completed in February of 1961 to correspond to the Design Criteria. During the construction phase of the work numerous field changes were made to facilitate the equipment installation, to improve operability.

(7) W. S. Kelly, Budget Study Report, Budget No. B-112-H, Fuel Testing Loop, HW-59227, February II, 1959.

(8) P. C. Walkup and W. S. Kelly, Scope Description - PRTR Fuel Element Rupture Test Facility, HW-62878, December 1, 1959.

(9) P. C. Walkup, et. al., Design Criteria for Fuel Element Rupture Test Facility, Project CAH-867, HW-63863, ApriI 1, 1960. 
and as the result of reviews by hazards authorities. The major changes and additions were:

1. Steel shielding was designed and installed around potentially contaminated equipment and piping inside the experimental cell of the containment vessel to minimize future personnel entry restrictions.

2. A second activity monitor sampling system was designed and installed.

3. The loop reactor safety circuit was revised:

(a) Reactor scram button and safety circuit bypass switch installed on the loop control panel.

(b) Loop safety circuit was expanded to include reactor shutdown and automatic loop cooldown on high differential pressure across the reactor test section.

4. The venting system for equipment outside the containment vessel was revised to enable better control of potentially contaminated fluids.

5. An emergency depressurization valve was installed and the emergency water injection and experimental cell process drain systems were revised to meet hazards requirements and to enable operation of the reactor with minimum effects from the loop under abnormal conditions.

6. A glove-box enclosed sampling system was designed and installed to provide manual sampling from various points in the system.

7. A leakage collection system was designed and installed in the experimental cell to collect and dispose of loop leakage separately from other experimental facility leakage.

8. A pumping system was designed and installed to improve personnel 
safety during the handling of makeup ion exchanger regeneration chemicals.

9. Emergency instrument air backup compressed air cylinder stations for critical loop control functions were designed and installed.

10. A complete mock-up of the high pressure assembly was designed and installed (connected to loop piping) in the experimental cell.

Design work on these changes was beyond the original design criteria. It was accomplished concurrently with the construction and completed in May of 1963. Finally, in May of 1963, a decision that NPR would not support operation of the facility caused redesign and fabrication of new jumper connectors to enable operation of the facility with PRTR fuel elements. This work was completed in October, 1963.

B. Construction

The construction work of the project included (1) construction of an underground building adjacent to the PRTR containment vessel to house part of the loop equipment, (2) construction of a water filtration plant to provide treated water to the loop facility and the PRTR secondary coolant system, (3) construction of a 75,000 gallon underground holdup tank with drain pump and connections, and (4) procurement and installation of loop facility equipment.

Items (1), (2) and (3) were undertaken by fixed price contractors and item (4) was undertaken by General Electric Co. (major equipment procurement) and by the on-site cost plus fixed fee contractor (equipment installation and material procurement).

The starting and ending dates for these construction phases were as follows: 
(1) Underground annex

(2) (3) Water Filtration Plant and Holdup Tank

(4) Procurement of Equipment

(5) Equipment Installation

\begin{tabular}{|c|c|}
\hline Started & Completed \\
\hline pt. 1960 & May 196 \\
\hline
\end{tabular}

Sept. 1961

August 1962

July $1960 \quad$ June 1963

July 1961

August 1963

The original project proposal scheduled beneficial use 17 months after authorization of funds (June of 1960) whereas the actual time from fund authorization to full beneficial use was 38 months. The major factors which accounted for the delay was inadequate estimation of possible delaying factors such as:

(a) Strike-delayed overall work progress two months.

(b) Administrative difficulties delayed start of work one month.

(c) Equipment procurement difficulties delayed progress three months.

(d) Design and field changes delayed final completion by six months.

(e) Unanticipated equipment difficulties delayed progress by four months.

(f) Limitations of personnel access to the containment vessel due to unusual operating problems (air activity) delayed construction completion by one month.

(g) Construction difficulties in making radiograph quality high pressure welds delayed final completion by one month.

(h) Completion of final design tests required three months prior to in-reactor installation. This was not anticipated in the original schedule. 
Copy Number

1

2

3
F. W. Albaugh

J. A. Ayres

J. M. Batch

D. C. Boyd

J. L. Boyd

J. J. Cadwell

J. E. Curtis

E. M. Davis

F. G. Dawson

D. R. DeHalas

R. F. Dickerson

R. L. Dillon

K. Drumbeller

E. A. Eschbach

R. F. Foster

J. C. Fox

M. D. Freshley

R. C. Frost

G. A. Halseth

H. E. Hanthorn

H. Harty

D. W. Hayes

R. A. Hemphill

H. L. Henry

O. F. Hill

P. L. Hoffman

E. R. Irish

R. T. Jaske

R. I. Junkins

A. R. Keene

R. A. Kennedy

D. R. Koberg

G. A. Last

$W . R$, Iewis

T. C. Mehas

R. L. Moore

D. E. Newby

J. M. Nielson

R. E. Nightingale

H. M. Parker

R. S. Paul

I. T. Pedersen

I. R. Pierce

A. M。 Platt

R. H. Purcell

W. D. Richmond

W. E. Roake

C. A. Rohrmann

D. P. Schively

R. K. Sharp 
INTERNAL DISTRIBUTION (conta.)

\section{Copy Number}

52

53

54

55

56

57

58

59

60

61

62

63

64

65

66

$67-90$

91-93
R. E. Skavdahl

R. I. Smith

J. A. Stoddard

C. R. Tipton, Jr.

J. C. Tobin

L. D. Turner

F. W. VanWormer

E. E. Voiland

P. C. Walkup

M. T. Walling

R. G. Sheeler

N. G. Wittenbrock

F.W. Woodfield

D. C. Worlton

K. L. Young

J. G. Zwiener

Extra

Central Files

EXTERNAL DISTRIBUTION

Copy Number

94-98 DIIE

